ROCZNIKI HUMANISTYCZNE

Tom LXIX, zeszyt $11-2021$

DOI: https://doi.org/10.18290/rh216911-5

VICENT CUCARELLA-RAMON

\title{
BLACK GHOSTS OF THE DIASPORIC MEMORY \\ IN JESMYN WARD'S SING, UNBURIED, SING
}

\begin{abstract}
A b s t r a c t. This article reads Jesmyn Ward's Sing, Unburied, Sing (2017) as a novel that follows an African American family facing the ghosts of their past and present to resurrect buried stories that are unrelentingly interlocked with the legacy of slavery and the draconian racist practices of Jim Crow. I posit that the novel participates in the re-examination of the trope of the ghost as a healing asset that needs to be accommodated within the retrieval of memory work. Thus, the enactment of this African diasporic memory facilitates the encounter with their ghosts so that the family can start their healing processes and be provided with the tools and examples of how to keep on coming to terms together with and against the legacy of slavery and the present racist practices.
\end{abstract}

Keywords: diasporic; memory; ghost; slavery; healing; racism.

Without memory can there be history?

Marlene NourbeSe Philip, She Tries Her Tongue

\section{INTRODUCTION: DIASPORIC MEMORY AND GHOSTLY ENCOUNTERS}

This article posits the centrality of the memory work that stems from the cultural legacy of the African diaspora as the means to nurture healing and self-assertion. Central to the retrieval of this memory is the figure of the ghost which acts as the motif that concentrates on the Black subject's suffering with the purpose of throwing into relief those processes of healing. In this way, the figure of the ghost becomes attached to the exercise of diasporic memory and,

Vicent CuCARELla-RAMON, Junior Lecturer at the Universitat de València, Department of English and German; e-mail: vicent.cucarella@uv.es; ORCID: https://orcid.org/0000-0003-1547-2273. 
therefore, plays an important role in the re-reading of memory studies and their new interpretations.

Memory studies have gained importance in the last three decades. In his determining article "The Generation of Memory: Reflections on the "Memory Boom' in Contemporary Historical Studies" Jay Winter explained the pervasive influence and obsession with memory in the field of humanities since it fleshes out "a multiplicity of social, cultural, medical, and economic trends and developments of an eclectic but intersecting nature" (364). The term "Memory Boom" was coined by Andreas Huyssen to point out the permanent concern with the multifarious ways in which the past still continues to infuse and inform the present. Accordingly, "the emergence of memory as a key concern in Western societies, a turning toward the past that stands in stark contrast to the privileging of the future so characteristic of twentieth century modernity" (Huyssen 21) has become a recent cultural asset and a critical tool not only in the fields of sociological and cultural studies but also in the realm of literary criticism. This is so because "the concept of cultural memory comprises that body of reusable texts, images, and rituals specific to each society in each epoch, whose 'cultivation' serves to establish and convey that society' self-image" (Assman 132). This move towards the recognition and study of the past to grapple with the maladies of the present for a better understanding of the future is clearly seen in the production of historical fiction in the literary market.

For the literature produced by African Americans, the politics of memory has always been a political act because it is fundamentally retrieved from their traumatic experience under slavery. In this way, the memory work brings forth a call for the cohesion of the community of African Americans and is thus located at the center of a cultural move to reclaim a suppressed history. For the generations of the African diaspora, the specifics of a past denied or silenced are never laid to rest as long as the memory of such acts remains unaddressed, if not overlooked, which induced Black people to make use of memory work with an eye to foster self-assertion and an eventual healing process. As Justine Tally rightly contends, "[t]his is especially true if ... physical and social segregation continued the process of subjugation and inferior treatment in American society for over 150 years after slavery was abolished" (31). In other words, "[w] hen not confronted, discussed or acted upon, the wounds do not heal, just deepen" (Irwin-Zarecka 25). Following this view, the revision and reclamation of the African American past by Black revisionists drew broadly on the Jewish experience and their ultimate success in reclaiming and exposing their silenced and repressed past as their path towards healing. 
Scholars started to coin the term "Black Holocaust" or else "Black Diaspora" to refer to their own history of slavery and dispossession. Out of this revision, the concept of diaspora began to appear unrelentingly linked to memory work and hence to the "fundamental presupposition that the memory of the homeland or original community must be carried forward into future generations, whether consciously or unconsciously" (Tally 35). This would be vitally important because throughout the nineteenth century there was an established train of thought that consolidated the idea that Africans were fit to be slaves because, as they had no written language, they had no memory and thus no connections whatsoever to their cultures or homeland. They seemed to embody a sort of tabula rasa on which white America found it easy to instill their own meaning. Therefore, the recovery of their diasporic memory will stand as the only chance to re-define themselves and to re-claim their ancestry and their cultural legacy in North America. In other words, "[r]obbed of everything, inscribed in the white man's literature, all that remained for the African slave was memory" (Tally 35). This diasporic memory, which manifests that "the Africans carried with them extensive knowledge, culture, and history" (Tally 35), got firmly validated through the oral tradition. In fact, as Maurice Halbwachs claims, the most obvious way in which the diasporic memory is enacted and formed is through stories and storytelling (38). For the critic, this is but a proof that the written word is no longer the embraced stable entity as it was accepted in the nineteenth century. Rather, the weight of orality on the memory work mastered by the cultural production of the African diaspora attests to the way in which the "individual thought places itself in these frameworks and participates in this memory that is capable of the act of recollection" (Halbwachs 38).

This assault on the (over)importance of the written word/text will be further used by Black writers to build upon the poststructuralist and postmodernist views in the interest of challenging conventional ways of thinking about notions as truth, reality, meaning or power. It is precisely in this interaction in which the literary trope of the ghost appears as a powerful asset in this re-visionary project played out by the literature of the African diaspora. Between the 1990s and the present, increasing scholarly attention has been paid to the figures of ghosts as, namely, representing the return of the repressed that haunts the living and pressingly calls for attention and/or justice. This is why it is particularly applicable to the historical record of Black people in North America. Conceived as a way to honor and voice both the legacy of the African past as well as the deathly presence of those who died along the infamous Middle Passage, the 
figure of the ghost stands, paradoxically, as a living presence in the literature of the African diaspora from the nineteenth century to this day. That is, it is also conjured up within the memory work. Joseph Roach goes on to explain that "the revolutionary potential of the spirit-world presence" (34) in African diaspora culture and literature from colonial and slavery times through Jim Crow bespeaks a well-encompassing potential that can be historically linked to the spiritual practices that often accompanied slave revolts. That is, these Black ghosts historically represent an act of cultural resistance. What is more, by being intertwined within the diasporic memory, the ghost is another trope that testifies to the African diasporic way to re-tell their own (hi)stories. Just as spiritualities that emerged and developed from African cultures "delineate a transgenerational diasporic community of the living and the dead, the lost and the forgotten, across national borders and historical periods" (Kaplan, "Souls at the Crossroads" 515), African diaspora writers' interest in, and inclusion of, ghosts in their texts can be seen as an affirmative and rehabilitating gesture of cultural and communal re-memory, to paraphrase the term coined by Toni Morrison, and re-membering. Indeed, Joan Chassot's seminal book Ghosts of the African Diaspora, published in 2018, seems aptly illuminating in the endeavor to keep on evaluating the importance of ghosts in African diasporic literature. In it, Chassot studies the link between memory and the trope of the ghost applying the theoretical framework to the novels of African American writers like Toni Morrison, Gloria Naylor, Fred D’Aguiar, Paule Marshall, and Michelle Cliff. To that group of known novelists who have delved into the literary trope of the ghost through memory work, I would like to add the awarded African American writer Jesmyn Ward's novel Sing, Unburied, Sing, published in 2017 and winner of the National Book Award for fiction the very same year. The story features the trope of the ghost to resurrect buried stories that are unrelentingly interlocked with the legacy of slavery and the draconian racist practices of Jim Crow. These acts are evoked through the use of diasporic memory since, as Marianne Hirsch elucidates, it helps survivors and their offspring to configure stories and images so powerful that they "constitute memories in their own right" (5). In so doing, these memories help to keep their fight alive as a necessary means for healing and for the eventual closure.

Thus, African diasporic literature appropriates the haunting ethos of the ghost to link it with memory aiming to foster "a form of consciousness for living the presence" (Chassot 27). Moreover, as I will study in Ward's novel, the trope of the ghost also stems from and gets unabashedly linked to the 
diasporic memory by means of passing on stories through oral tradition and hence certify the cultural background of the African diaspora by challenging the established and restrictive value of the written word, used historically to prove the inhumanity of African people, and therefore validates Paul Ricoeur's statement that " $[\mathrm{t}]$ estimony constitutes the fundamental transitional structure between memory and history" (21). In this sense, by mixing ghostly stories and memory work the novel taps into a "legacy which appears in the form of unresolved memory traces and occluded histories resulting from the experience of colonial oppression" and the legacy of slavery readily figured in the shape of "ghosts ... that 'haunt' the subjects from without and within" (Sugars and Turcotte, 2009: vii). As a result, I will contend how the presence of these ghosts allows the Black family in Sing, Unburied, Sing, to re-accommodate their past into the present and to accept the porous line that separates life and death since, this way, their ancestors will always be present in their everyday quest and fight toward justice and healing.

\section{DIASPORIC MEMORY AND ITS GHOST(S) IN SING, UNBURIED, SING}

The novel is set in the fictional town of Bois Sauvage and tells the story of an outcast African American family and their struggle to thrive and survive the multiple violence they have been subjected to. The tale is told in fragmented voices and recounts the same events from different perspectives. It follows the character of Jojo, a mixed-race 13-year-old-boy who lives with her mother Leonie, a drug addict, and her baby sister, Kayla. His white father is imprisoned and they live in his grandparents' house. The role of the old couple, Pop and Mam, becomes crucial for the developing of the story. On the day the novel begins Jojo is to embark on a haunting journey with her mother and sister to pick up his father from prison. This trip will be used to unearth symbolic and literal ghosts of the past that will be central to set up the path of healing.

In a typical Wardian move, the epigraphs that open the novel offer an enlightening explanation of what the novel's "ideology of form" is going to be about. ${ }^{1}$ Out of the three excerpts that Ward has chosen to frame her

\footnotetext{
${ }^{1}$ Jesmyn Ward's use of epigraphs as texts that open the interpretations of her stories become a revealing move in her novels. This is also the case of her previous book, Salvage the Bones, a typological story of sin and redemption that revisits the tragedy of Hurricane Katrine and its various impacts on a poor African American family. I have dealt with this topic elsewhere (Cucarella-Ramon 2020).
} 
narrative, two revolve around memory and diaspora. The first one refers to an African chant which reclaims Olaudah Equiano's presence as a foundational figure and representative of the African diasporic subjects: "Who are we looking for, who are we looking for?... It's Equiano we're looking for" (Sing, Unburied, Sing 0, SUS henceforth). The second epigraph draws from Eudora Welty's One Writer's Beginnings and deals with the importance of memory for the survival of a community: "The memory is a living thing" (SUS 0). These two allusions help to frame the novel's story but also set the tone of the message that the novel displays taking into consideration the different historical moments ingrained in it. Certainly, the coupling of memory and diaspora appears crucial to understand the haunting story in which Jojo and his family will have to eventually come to terms and live with their own ghosts in order to achieve a yearned peace of mind and healing.

Jojo's opening words work as a stalwart statement and offer a clue about the ontological journey he is about to undertake: "I like to think I know what death is" (SUS 1). The pervious line that separates life and death will be a constant reminder throughout the whole novel and establishes the conflicting moves of the characters. That is, it foregrounds the ghostly interpersonal connection of some characters haunted by far-reaching and racialized injustices. Truthfully, different types of death permeate the novel. Indeed, it is fit to say that some deaths in the novel serve as catalysts to promote the potentiality of diasporic memory as an agent for survival and they also lead to the eventual process of healing once the product of such deaths, the ghost, is accommodated as part of their history and identity. And yet, there is only one character to whom death serves neither as a process of healing nor as a final act of redemption: Leonie. Her self seems to be doomed from the very beginning of the story. Not only is she a drug addict but she is also a woman that has suffered floods of racist attacks by her in-laws for having eloped with their white son. Her conception of the self is also utterly damaged by the family tragedies she has endured. All this has led her to become and obsessive woman with a problematic love for her children and an inability to reconnect with the ghosts of the past. This volatile behavior prompts her offspring to take center stage and take care of each other thus rewriting the children's love for their mother. This is the exact case for Jojo who has to devote her attention to his little sister to fill in his mother's recklessness to the extent that Leonie sometimes thinks of him as a daughter: "I look at him and see a hungry girl" (SUS 95), or regards him with jealousy: "I stand there, watching my children comfort each other" (SUS 101), "They are each other's light" (SUS 51). In both cases, the children shift their 
position with their mothers and gain self-assertion whilst they also expose the crumbling of a sense of motherhood fatally hit by racism and desperation.

This is why Jojo turns to his grandparents for a model and comfort. In particular, Jojo's grandad, Pop, plays a pivotal role in his awakening to adulthood and to take on his role as the family guide. However, the boy will learn that his adored grandfather has a staggering secret he has held back throughout his entire life. Pop was imprisoned at the penitentiary of Parchman on a false charge at the age of 15. There, he met 12-year-old boy Richie and took him under his wing. The young kid had been jailed accused of having robbed to help his family. None of the two sentences mentioned seem to have really happened, which brings to the fore the infamous procedures of the wrongful and racist judicial system. The atrocities of slavery that have their effect on African slaves is transposed here to the neo-slavery regime (Alexander 31) that the judicial system represents for Black people in the US which, in Pop's own words, stands for "a place for the dead" (SUS 96). The prison term turns out to be extremely hurtful and degrading for the Black convicts. Despite Pop's protection, Richie is oftentimes mocked and ill-treated by other inmates due to his alleged homosexuality (SUS 75). On a given day, the kid broke his hoe and that acted as the perfect excuse to get brutally beaten by a gang of convicts. He was so deleteriously whipped that his back wound up being totally destroyed. This abhorrent act of violence unites the young kid and Pop to the extent that from this moment on, their destiny will be sealed until the end of the story trespassing the traumatic hands of time. Though unbeknownst to him, Jojo knows that something contemptible happened between the young boy and his grandfather the day that he gets to see Richie's ghost. In fact, he is the only one who can see the kid's ghostly presence- "a dark skinny boy with a patchy afro and a long neck" (SUS 130)—and though he knows the boy died he wants his grandfather to tell him what really the cause was. This quest becomes even more obsessive when Richie's ghost gets demanding for answers and for a closure with just one action required: "to memory" (SUS 136). Richie's allusion "to memory" points to the importance of retrieving the role of diasporic memory to revisit the violence historically inflicted on Black people. Indeed, this reenactment of memory in Sing, Unburied, Sing is very much premised on "the nature of memory, and survival" (Tally 32 ). So, if "[m]emory makes life pleasant [but] forgetfulness makes it possible" (Tally 33), resorting to diasporic memory in the story will become deciding to understand how to overcome the past, understand the present and to achieve survival. This memory will be retrieved through testimonies and songs, that is, through oral tradition 
which will be the ideal means to counteract the legacy of racism by stripping off its real repercussion and, therefore, to vent resistance. Trudier Harris also attests to this convention when she avows that "orality is one of the keys to unlocking African American literary history" (1). In this vein, for the African diaspora "the most obvious way in which memory is incited, formed, and complemented is through stories and storytelling" (Tally 39). Consequently, in Ward's novel, diasporic memory will be the key to reconstruct the true story of the family to lay the foundation of the final process of healing.

More often than not, Pop's confessions to Jojo take place in the woods and at the hearth, connecting such acts of orality with their African past. The return and presence of Richie's ghost triggers this need of confessing and opens the old man's buried secrets that have thwarted his ability to carry on and accept his past. Saidiya Hartman analyzes how the elements of African cultures persist in the legacy of the diaspora using tropes such as the ghost that serves to exemplify how such "elements are created, imagined, and remembered" (72) in the quest for survival. It is thanks to the workings of such diasporic memory that Pop will finally pass on the story and will face his actions and destiny. Indeed, his memories of violence and racism will bring him back to remember the experience of his ancestors in the Middle Passage when recounting his traumatic stay in prison: "she'd come across the ocean, been kidnapped and sold. Said her great-grandma told her that in her village, they ate fear.... She learned that bad things happened on that ship,... that her skin grew around the chains. That her mouth shaped to the muzzle" (SUS 69). Indeed, Parchman bears a resemblance to a slave plantation: the Black inmates are obliged to work, they are "chained" (SUS 186), if they escape, they are chased with dogs and when caught they are either hanged or lynched. Briefly put, Pop reflects on slavery memories to visualize the reality of the contemporary US, that is, Parchman prison acts for the modern plantation in which the nefarious legacy of slavery finds a new format. ${ }^{2}$ As Michell Alexander makes clear, "since the nation's founding, African Americans repeatedly have been controlled through institutions such as slavery and Jim Crow, which appear to die, but then are reborn in new form" (21). Ward herself has acknowledged and demanded the traumatic past that stems from slavery to be taken into account to fully understand the current racist policies, especially those revolving around the ignominious policing of Black lives. In her latest book of essays, she strongly

\footnotetext{
${ }^{2}$ This contention is reinforced by David Oshinky's study of Parchman in which he does not hesitate to assert that the prison might as well be seen as "the closest thing to slavery that survived the Civil War" (2).
} 
avows people to remember "how inextricably interwoven the past is in the present, how heavily the past bears on the future" and thus "we cannot talk about lives mattering or police brutality without reckoning with the very foundation of this country" ("Introduction" 9). The foundation, according to the author, is the link between slavery and current practices of ongoing racism following Jim Crow laws, such as the aforementioned police brutality and mass incarceration. Therefore, as the novel hints at, it is determining that "we must acknowledge the plantation, must unfold white sheets, must recall the Black diaspora to understand what is happening now" ("Introduction" 9). With these words, Ward points out to the way in which Pop's memory needs to be read going all the way to slavery, that is, to the foundations of suffering to the African diaspora up to this day. In so doing, the novel partakes in Chassot's revision of the ghostly properties of diasporic memory that expounds the way in which "African diasporic cultural practices ... were born on, or from, the Middle Passage itself" (53) whilst, concurrently, Ward takes the opportunity to concretize the historical continuum of violence, racism and exclusion that links slavery with the current and racist system of mass incarceration. ${ }^{3}$

This link is utterly upheld by memory, that is, by remembering the whole history of violence against Black people in the US. In Nicole Dib's own words: "the story of [Pop]'s family's Middle Passage, the grip that the afterlife of slavery has on their lives, is unburied in the process of recounting his own encounters with the unfreedom that built today's carceral state" (140). In this light, and thanks to the foregone encounter with the ghost, the two conceptions of diasporic memory related to the afterlife are branched off in Sing, Unburied, Sing. These two modes of memory, as Justine Tally has studied, are "what Ricoeur calls 'reminiscence', which entail an active search for past experience (via storytelling and the construction of the past), and 'phantasma', which is totally involuntary - and therefore more trustworthy as 'fact' — because it is prompted by an association, or repetition of the past" (Tally 42). In Ward's story, Richie's ghost represents the "reminiscence" whilst Given, Leonie's brother who died murdered by a white friend, returns as a ghost that embodies the "phantasma". Tellingly, "no black characters in the novel ever question the actual existence of ghosts" (Tally 59) since their presence will be of help with an eye to grasp the family's peace of mind. Yet, the overlapping of these

\footnotetext{
${ }^{3}$ It is interesting to call attention to the fact that Nicole Dib turns to Spillers's theorization to link "the Middle Passage and black mobility" to "also show the violent rupturing of kinship ties that resulted from such forced travel" (139). In this way, Pop's open door to recount his experience in the prison/plantation of Parchamn is enacted thanks to Jojo's Middle passage/trip to the same prison in order to pick up his father.
} 
two ghostly presences open the way for different kinds of healing always connected with the past and, accordingly, achieved by means of memory work.

In this vein, Richie, as a "reminiscence", is in search of the actual truth of his death so that he can finally rest and go "home" (SUS 182). This demand can only be provided by Pop who was there when the kid was killed. However, the confession will wind up changing the old man and the kid's ghost forever. After a series of questions and an ongoing persecution, Jojo eventually surrenders to Richie's request and asks Pop about the incident that steered towards the killing of the boy. Pop tells the story and its invocation turns into a moment of redemption at length. According to the grandfather's story, Richie discovered the atrocious act committed by Blue, a violent inmate who raped a woman, when they were caught and thus stood no other chance than fleeing. They were chased and eventually captured. Much to his dismay, Pop was in charge of leading the dogs that had to follow the two fugitives. Once he got Richie, he realized that he would be lynched for being (falsely) accused of raping a white woman and, in a move that brings to mind Toni Morrison's Beloved, solely to spare him suffering, decided to kill the boy by sticking a pick in his neck (SUS 255).

Pop's confession performs Paul D's opening of the "tobacco tin blown open" (Morrison 218) since it frees him from remorse and guilt. Though the old man collapses and breaks down, this loss of control exposes his redemption and his path towards a final healing. The outcome of the attack is very telling: the disappearance of the ghost. Richie disappears owing to the fact that his ghostly presence was justified because their story had been left unresolved. When Pop comes to terms with his acts and his family and redeems his guilt over understanding and forgiveness, Richie's role as ghost vanishes for his ubiquity was justified as "part of [familial] experience" (13), as Lynette Carpenter states. In this way, the figure of the ghost is a catalyst both to enact the memories and to voice, accept and overcome the trauma of the "unsayable" and hence aligns with memory work "to acknowledge one's knowledge, to face the secret, to claim one's darker self" (Fedorko 85).

On the other hand, there is the importance of the other ghost of the story, Given, who, as a "phantasma", appears link to Mam's and Leonie's memories. His presence is only seen by his sister when she is high and, therefore, at ease. In this sese, he acts as a sort of ghostly conscience who reminds her inability to perceive the healing potential of the ghosts since he recalls the importance and power of familial love and thus he has "Mama's face" (SUS 234), which, according to Leonie's desertion of her role as a mother, throws into relief the 
importance of motherhood as a "central theme" (Carpenter and Kolmar 18) in ghost stories. Linked to motherhood, these ghosts are only appraised and thus valuable for healing if they can possess "a quality of familiarity" (Carpenter and Kolmar 12). The ghost of Leonie's brother can only serve to conjure up a trauma "that one doesn't yet know" (Chang 125). However, Given's ghost, which is mostly celebrated in the story as his mother's way of clinging to life, will have to front Richie's at the moment of Mam's passing. The "spiteful" (Morrison 3) odor of 124 Bluestone Road is reenacted as "vengeful" (SUS 264) in the moment in which Richie's ghost comes to take Mam to the world of the dead. The old woman had previously asked her daughter to collect "the littany" (SUS 267), that is, a sort of prayer to Maman Brigitte who happens to be a mystère or, in other words, a kind of intermediary spirit known as the "Mother of the Dead". Such resort to African spirituality connects Mam to her ancestors so that she can transcend in peace. The old man leaves with no confession and no sharing of experiences with her daughter, which, again, proves Leonie's incapacity to get her familial bonds together. This will soon prompt her to leave for good, missing the opportunity to use her connection to Given's ghost - since she cannot see him if she is not high — to foster her healing and wholeness. Once Mam is gone, Richie's company also disappears, as he had previously done before Pop and Jojo. As the young boy finally cries out: "Ain't no more stories for you here" (SUS 268). Once Mam is dead, the sky turns a sort of carmine red (SUS 274) which, as in Beloved following the episode of Amy going to buy carmine velvet (Tally 58), speaks of Mam's connection to Africa and the reunion with her dead ancestors: "with everybody else that's gone before" (SUS 236). Mama becoming also a ghost reinforces the common ground between the legacy and offspring of the African diaspora and displays another illustration and reaffirmation of what Joan Chassot alleges as the potentiality of the "link to Africa on which diasporic memory and identity are founded" (31).

Besides, Mam's death and ghost triggers Leonie's unvarnished acceptance of her real role in the family: "I can't be a mother right now. I can't be a daughter" (SUS 274). The old woman's disappearance allows for the clarification of roles and Leonie accepts that she cannot bear to "pretend at forgetting" (SUS 275). However, once Mam is gone and Leonie runs off with her husband, Jojo makes peace with her mother because he realizes that his real mother has always been Mam, who also serves as a link with the ancestors and helps to make sense for the presents of ghosts as part of their identity and life: "Now you understand life. Now you know" (SUS 282). The novel ends with everyone in the family 
understanding their place and with their healing process accommodated. Mam is now a new familial ghost reunited with her ancestors and reconvened with the victims of the Middle Passage and the Black victims of mass incarceration: "rags and breeches, T-shirts and tignons, fedoras and hoodies" (SUS 282). Again, the aforesaid continuum is stirred up and consolidated because, as Geraldine Smith-Wright posits, the ghosts in the African American tradition are rooted in slavery and keep watching over using the beliefs of the afterlife prevalent in Africa to this day (160). In this precise and meaningful moment little Kayla starts to sing a song that Mam knew, just like Beloved's ghost sang Sethe's tune, bringing to the fore the yearned moment of final healing and unity for the family merging life and afterlife, "like relief, something to remembrance, something like ease" (SUS 284). Again, storytelling and orality appear united to the afterlife as a process that encompass familial bonds and communal healing. This unity, understanding and shared love between Pop, Jojo and Kayla with their ghosts, is the way to "put their story next to their ancestors" to secure their "kind of tomorrow" (Morrison 273). The diasporic memory brought about by these familial ghosts help to make clear "the way in which the future is always already populated with certain possibilities derived from the past" as Wendy Brown analyzes (Brown 36). This is the reason why the final familial trinity (Pop, Jojo and Keila) understand that the diasporic memory teaches them that their life is forever filled with their ghosts - "[t]he ghosts shudder, but they don't leave" (SUS 284)-since they help them to come to terms with the hurtful legacy of slavery up to the legal injustices of the present. That Jojo and Kayla are mixed-race subjects adds up another layer of significance to this act of learning and to the ultimate healing process since it points to an also inclusive racial heritage within the ghosts of the African diaspora in the quest for equality and respect.

The novel contributes thus to Chassot's statement that "African diaspora literature invites us to live with ghosts" (33). Accordingly, in the end, the family knows that healing is possible as long as they accommodate their past to fight for their present so that they can always have the ghosts of their ancestors reminding them that they stand a true chance to finally reach " $[h] o m e$, they say. Home" (SUS 285). 


\section{CONCLUSION}

In the recent re-evaluation of the healing ethos attached to the ghosts of the African diaspora, Jesmyn Ward's Sing, Unburied, Sing centers its interest on the presence of the familial ghost(s) and the type of diasporic memory that accompanies their appearance in order to delve into the fissures of a poor and depraved African American family that has fallen victim of insitutionalized racism. In so doing, Ward builds upon Joan Chassot's framework and inscribes her novel in the tradition of stories that walk the line that facilitates the encounters with the ghosts of the African diaspora and their assigned healing features since the gaps left by their absence turn into a source of questioning and a quest for sources toward self-understanding. Interestingly, and following the current momentum of police brutality and the relentless crisis of mass incarceration, Ward takes a step further and enters upon the current sociocultural reality in the US by evoking Parchamn prison, where Pop and the young Richie were jailed, a move that careens toward the reenactament of (neo)slavery that the prison system actually represents and symbolizes for African Americans and, in this way, belabors the new forms of the pervasive legacy of slavery inscribed in African America.

Bearing in mind this link to the violence inflicted by the "peculiar institution" and its renewed pratices, Ward makes use of the trope of familial ghosts to exorcize the pain and the resulted trauma searching out to find healing, especially when this violence leads to wrong choices. In this sense, Pop needs to do away with the grief and remorse for having killed Richie out of protection and unreserved love. This will serve as an example to Jojo who will wind up taking the lead of the family once his mother Leonie finally disappears after the death of Mam, the real matriarch, proving her disconnection with her family and, therefore, her incapability to read and commnunicate with the ghost of her late brother Given. Mam will also stand as the ultimate familial ghost after passing away and connectin, and communicating, with the deceased African Americans both from the past and from the present. Thence, the novels insists on relying on the potential of the oral tradition, against the restriciting prevalence of the written word, to pass on and highlight the validity and importance of diasporic memory in the process of self-assertion. Hence, this ending showcases and reinforces, yet again, the bond between the African ancestors and the current generation of the African diaspora. All in all, Ward presents the final familial trinity at ease with the omnipresent presence of their ghosts, their "home", who bring along the diasporic memory that breathes them 
their meaning and also provide them with the tools and examples of how to keep on coming to terms together with and against the legacy of slavery and the present racist practices.

\section{WORKS CITED}

Alexander, Michelle. The New Jim Crow Mass Incarceration in the Age of Colorblindness. The New Press, 2010.

Assman, Jan. "Collective Memory and Cultural Identity." Translated by John Czaplicka, New German Critique, vol. 65, 1995, pp. 125-133.

Brown, Wendy. "Specters and Angels at the End of the Story." Vocations of Political Theory, edited by Jason A. Frank and John Tambornino, U of Minnesota P, 2000, pp. 34-45.

Carpenter, Lynette. "Introduction". Haunting the House of Fiction: Feminist Prespectives on Ghosts Stories by American Women, edited by Lynette Carpenter and Wendy K. Kolmar, U of Tennessee P, 1991, pp. 1-25.

Carpenter, Lynette, and Wendy K. Kolmar, editors. Haunting the House of Fiction: Feminist Perspectives on Ghost Stories by American Women. U of Tennessee P, 1991.

Chang, Shu-li. "Daughterly Haunting and Historical Traumas: Toni Morrison's Beloved and Jamaica Kincaid's The Autobiography of My Mother." Concentric, vol. 30, no. 2, 2004, pp. 105-127.

Chassot, Joan. Ghosts of the African Diaspora: Re-visioning History, Memory and Identity. Dramouth College P, 2018.

Cucarella-Ramon, Vicent. "Biblical Echoes and Communal Home in Jesmyn Ward's Salvage the Bones." Miscelanea: A Journal of English and American Studies, vol. 62, 2020, pp. 91-107.

Dib, Nicole. "Haunted Roadscapes in Jesmyn Ward's Sing, Unburied, Sing." MELUS, vol. 45, no. 2, 2020, pp. 134-153.

Fedorko, Kathy A. "Edith Wharton's Hauned Fiction: 'The Lady's Maid's Bell' and The House of Mirth." Haunting the House of Fiction: Feminist Perspectives on Ghost Stories by American Women, edited by Lynette Carpenter and Wendy K. Kolmar, U of Tennessee P, 1991, pp. 80-107.

Harris, Trudier. Fiction and Folklore: The Novels of Toni Morrison. U of Tennessee P, 1991.

Hartman, Saidiya. Scenes of Subjection: Terror, Slavery, and Self-Making in Nineteenth-Century America. Oxford UP, 1997.

Hirsch, Marianne. The Generation of Postmemory: Writing and Visual Culture after the Holocaust. Columbia UP, 2012.

Huyssen, Andreas. Twilight Memories: Marking Time in a Culture of Amnesia. Routledge, 1995.

Irwin-Zarecka. Frames of Remembrance: The Dynamics of Collective Memory. Transaction Publishers, 2007.

Kaplan, Sarah Clarke. "Souls at the Crossroads, Africans on the Water: The Politics of Diasporic Melancholia." Callaloo, vol. 30, no. 2, 2007, pp. 511-526.

Morrison, Toni. Beloved. Plume, 1998.

Oshinky, David. “Worse than Slavery”: Parchamn Farm and the Ordeal of Jim Crow Justice. Free Press, 1996. 
Ricoeur, Paul. Memory, History, Forgetting. Translated by Kathleen and David Pellauer, U of Chicago P, 2004.

Roach, Joseph. Cities of the Dead: Circum-Atlantic Performance. Columbia UP, 1996.

Smith-Wright, Geraldine. "In Spite of the Klan: Ghosts in the Fiction of Black Women Writers." Haunting the House of Fiction: Feminist Prespectives on Ghosts Stories by American Women, edited by Lynette Carpenter and Wendy K. Kolmar, U of Tennessee P, 1991, pp. 142-165.

Sugars, Cynthia, and Gerry Turcotte, editors. Unsettled Remains: Canadian Literature and the Postcolonial Gothic. Wilfried Laurier UP, 2009.

Tally, Justine. Beloved: Origins. Routledge, 2009.

Ward, Jesmyn. Sing, Unburied, Sing. Scribner, 2017.

Ward, Jesmyn. "Introduction." The Fire This Time: A New Generation Speaks About Race, edited by Jesmyn Ward, Bloomsbury, 2019, pp. 1-10.

Winter, Jay. "The Generation of Memory: Reflections on the 'Memory Boom' in Contemporary Historical Studies.” Canadian Military History, vol. 10, no. 3, 2011, pp. 57-66.

\section{CZARNE DUCHY PAMIĘCI DIASPORY W ŚPIEWAJCIE, Z PROCHÓW, ŚPIEWAJCIE JESMYN WARD}

Streszczenie

W powieści Jesmyn Ward Śpiewajcie, z prochów, śpiewajcie (2017) afroamerykańska rodzina musi stawić czoła duchom przeszłości jak i teraźniejszości, wskrzeszając dawno pogrzebane historie, które są ściśle splecione z dziedzictwem niewolnictwa i erą surowych praw Jima Crowa. Artykuł stawia tezę, iż powieść bierze udział w reinterpretacji postaci ducha jako uzdrawiającego czynnika, który należy koniecznie uwzględnić w procesie odzyskiwania pamięci. Dlatego ożywienie pamięci afrykańskiej diaspory przyspiesza spotkanie z duchami, dzięki czemu rodzina może rozpoczą́ proces uleczania, otrzymując narzędzia i wzorce umożliwiające pogodzenie się z dziedzictwem niewolnictwa i współczesnymi przejawami rasizmu.

Słowa kluczowe: diaspora; pamięć; duch; niewolnictwo; uzdrowienie; rasizm. 